\title{
Correction to: Changing the Church
}

\author{
Mark D. Chapman and Vladimir Latinovic
}

\section{Correction to:}

M. D. Chapman, V. Latinovic (eds.), Changing the Church, Pathways for Ecumenical and Interreligious Dialogue, https://doi.org/10.1007/978-3-030-53425-7

This book was inadvertently published with the titles of the section $\mathrm{V}$ and section VI swapped. This has now been amended in the book.

The updated version of the book can be found at https://doi.org/10.1007/978-3-030-53425-7

(C) The Author(s), under exclusive license to Springer Nature Switzerland AG $2021 \quad \mathrm{Cl}$ M. D. Chapman, V. Latinovic (eds.), Changing the Church, Pathways for Ecumenical and Interreligious Dialogue, https://doi.org/10.1007/978-3-030-53425-7_42 